\title{
New Textile for Personal Protective Equipment-Plasma Chitosan/Silver Nanoparticles Nylon Fabric
}

\author{
Cláudia M. Botelho ${ }^{1, *}$, Margarida M. Fernandes ${ }^{1,2}{ }^{,}$Jefferson M. Souza ${ }^{3}$, Nicolina Dias ${ }^{1}$, Ana M. Sousa ${ }^{1}$, \\ José A. Teixeira $\left.{ }^{1} \mathbb{(}\right)$, Raul Fangueiro ${ }^{4} \mathbb{D}$ and Andrea Zille ${ }^{4}(\mathbb{D}$ \\ 1 CEB - Centre of Biological Engineering, Universidade do Minho, 4710-057 Braga, Portugal; \\ margaridafernandes@fisica.uminho.pt (M.M.F.); nidias@deb.uminho.pt (N.D.); \\ anamargaridasousa@deb.uminho.pt (A.M.S.); jateixeira@deb.uminho.pt (J.A.T.) \\ 2 Centro/Departamento de Física, Universidade do Minho, 4710-057 Braga, Portugal \\ 3 CBMDE, Design and Styling, Federal University of Piauí, Teresina, PI 64049-550, Brazil; jefferson@ufpi.edu.br \\ 4 2C2T-Centro de Ciência e Tecnologia Têxtil, Universidade do Minho, 4800-058 Guimarães, Portugal; \\ rfangueiro@civil.uminho.pt (R.F.); d3742@det.uminho.pt (A.Z.) \\ * Correspondence: claudiabotelho@deb.uminho.pt; Tel.: +35-19-6636-5977
}

Citation: Botelho, C.M.; Fernandes, M.M.; Souza, J.M.; Dias, N.; Sousa, A.M.; Teixeira, J.A.; Fangueiro, R.; Zille, A. New Textile for Personal Protective Equipment-Plasma Chitosan/Silver Nanoparticles Nylon Fabric. Fibers 2021, 9, 3. https:// doi.org/10.3390/fib9010003

Received: 4 November 2020 Accepted: 1 December 2020 Published: 6 January 2021

Publisher's Note: MDPI stays neutral with regard to jurisdictional clai$\mathrm{ms}$ in published maps and institutional affiliations.

Copyright: (C) 2021 by the authors. Licensee MDPI, Basel, Switzerland. This article is an open access article distributed under the terms and conditions of the Creative Commons Attribution (CC BY) license (https:// creativecommons.org/licenses/by/ $4.0 /)$.

\begin{abstract}
Fabric structures are prone to contamination with microorganisms, as their morphology and ability to retain moisture creates a proper environment for their growth. In this work, a novel, easily processed and cheap coating for a nylon fabric with antimicrobial characteristics was developed. After plasma treatment, made to render the fabric surface more reactive sites, the fabric was impregnated with chitosan and silver nanoparticles by simply dipping it into a mixture of different concentrations of both components. Silver nanoparticles were previously synthesized using the Lee-Meisel method, and their successful obtention was proven by UV-Vis, showing the presence of the surface plasmon resonance band at $410 \mathrm{~nm}$. Nanoparticles with $25 \mathrm{~nm}$ average diameter observed by STEM were stable, mainly in the presence of chitosan, which acted as a surfactant for silver nanoparticles, avoiding their aggregation. The impregnated fabric possessed bactericidal activity higher for Gram-positive Staphylococcus aureus than for Gram-negative Pseudomonas aeruginosa bacteria for all combinations. The percentage of live $S$. aureus and P. aeruginosa CFU was reduced to less than $20 \%$ and $60 \%$, respectively, when exposed to each of the coating combinations. The effect was more pronounced when both chitosan and silver were present in the coating, suggesting an effective synergy between these components. After a washing process, the antimicrobial effect was highly reduced, suggesting that the coating is unstable after washing, being almost completely removed from the fabric. Nevertheless, the new-coated fabric can be successfully used in single-use face masks. To our knowledge, the coating of nylon fabrics intended for face-mask material with both agents has never been reported.
\end{abstract}

Keywords: fabric; infection; chitosan; silver nanoparticles; antimicrobial; facemask

\section{Introduction}

Considering the actual pandemic situation that we are living and the increasing use of masks by the population, it is of paramount importance to develop novel antimicrobial textiles that could be used either in a medical context, for hospitalized patients and hospital staff, or for generalized use as face mask. Fabrics have an ideal environment for the growth of microorganisms. They are porous, retain water and, as they are close to human body, their normal temperature is approximately $37^{\circ} \mathrm{C}$. The constant use of facial masks and protective clothes, if not used properly, increases the risk of infection. A fabric with antimicrobial properties is, in fact, essential to overcome this problem.

The antimicrobial properties of silver have been known for many years. Silver is currently used in several medical devices, like wound dressings, coating of surgical instruments and prostheses [1]. With the advances of technology, silver nanoparticles (AgNPs) 
have been widely prepared and demonstrated to possess high antimicrobial potential. They are now considered a good alternative to antibiotics, although their use for medical applications can be hindered due to its high toxicity to the patient and the environment [2] It is known that AgNPs can enter the human body by different ways and accumulate in different organs, but most important, they can cross the blood-brain barrier and reach the brain [1]. Thus, there is the need to decrease the AgNPs' toxicity but keep their antimicrobial properties. One approach is the incorporation of the AgNPs in a biocompatible polymer like chitosan, which has intrinsic antimicrobial properties, creating a synergy between the two materials [3,4]. An interesting fact is that AgNPs nanoparticles have demonstrated an efficient inhibitory activity against human immunodeficiency virus (HIV1) $[5,6]$, hepatitis B virus (HBV) [7], respiratory syncytial virus herpes simples virus type $1[8,9]$, monkeypox virus plaque formation [10] and influenza H1N1 virus [11]. A very recent study claims that silver may be effective on the treatment and prevention of COVID-19 and SARS-COV-2 [12].

Plasma-assisted polymerization and sputtering is one of the most used techniques for nanomaterials' deposition at an industrial scale $[13,14]$. However, this technique presents significant limitations like low deposition rate, sample size, batch operation, limited electrodes spacing and expensive vacuum systems [15]. Atmospheric pressure plasma can be considered an alternative to plasma-assisted polymerization and sputtering, as it is a cost-competitive method when compared to wet chemical treatments and lowpressure plasma, allowing continuous and uniform processing of fibers' surfaces [16]. Double Dielectric Barrier (DBD) plasma is considered the most effective cold atmospheric plasma source, and it has been widely applied for surface activation and deposition of thin functional coatings $[17,18]$.

Therefore, in this work, a DBD plasma pretreated nylon fabric was functionalized by a simple dip coating method with a mixture of different concentrations of AgNPs and chitosan. The characteristics of the textile were analyzed, as well as the synergistic effect of the active agents. Silver-based nylon fabric has long been known to act as an antimicrobial agent for wound therapy, helping the mitigation of wound infection and inflammation [19]. The synergistic effect of silver and chitosan has also been proven to be effective for preventing the agglomeration of AgNPs and improve its biocompatibility $[3,20]$. To our knowledge, a nylon coating intended for face masks material with both agents has never been reported.

\section{Materials and Methods}

\subsection{Materials}

Chitosan (ChitoClear hq95-43000) was acquired from Primex (Siglufjordur, Iceland), and polyamide taffeta with 52 warp and 32 weft yarns, with an areal density $100 \mathrm{~g} \mathrm{~m}^{-2}$, was acquired from Lemar (Guimarães, Portual). All the other reagents were purchased from Sigma-Aldrich (St. Louis, Missouri, EUA) and used without further purification.

\subsection{Nanoparticles Synthesis}

A $0.02 \mathrm{gL}^{-1}$ colloidal dispersion of AgNPs was prepared, using the modified method described by Lee and Meisel [21]. All solutions were prepared in distilled water, and the dispersion was subjected to a vigorous mixing. A volume of $10 \mathrm{~mL}$ of $1 \%$ trisodium citrate $\left(\mathrm{Na}_{3} \mathrm{C}_{6} \mathrm{H}_{5} \mathrm{O}_{7}\right)$, as reducing agent, was added drop-by-drop to $100 \mathrm{~mL}$ of $1 \mathrm{mM}$ silver nitrate $\left(\mathrm{AgNO}_{3}\right)$, which was previous heated to boiling point in a $250 \mathrm{~mL}$ flask, reaching a final concentration of $3.8 \mathrm{mM}$. The $\mathrm{pH}$ of the reaction was adjusted to 7.7 by adding $\mathrm{NaOH}$ at the end of the fast nucleation stage, to stop the reaction. The solution was heated again, to boiling temperature, until color's change was evident (pale yellow). At this stage, the solution was cooled to room temperature, while mixing. The resulting colloidal solution presented high stability, i.e., the aggregation of the NPs was very low for 2 months, when stored at $4{ }^{\circ} \mathrm{C}$. 


\subsection{Preparation of Chitosan Solution}

Chitosan was prepared in a concentration of $0.5 \mathrm{wt} \%$. Chitosan $(0.5 \mathrm{~g})$ was dissolved in $2 \mathrm{~mL}$ of acetic acid (glacial), to completely dissolve the chitosan, and distilled water was further added, until we reached $100 \mathrm{~mL}$ of solution, and stirred at $300 \mathrm{rpm}$ for $30 \mathrm{~min}$.

\subsection{Nylon Fabric Plasma Treatment}

To improve the adhesion of the coating, plasma treatment was applied prior to the application of the antimicrobial agents. The Double Dielectric Barrier plasma was applied in a semi-industrial prototype machine (Softal Electronics $\mathrm{GmbH} /$ University of Minho, Guimarães, Portugal), at room temperature and atmospheric pressure. A metal electrode coated with ceramic and counter electrodes coated with silicon with an effective width of $50 \mathrm{~cm}$ and a gap distance of $3 \mathrm{~mm}$ were used to induce a $10 \mathrm{kV}$ high voltage discharge and a $40 \mathrm{~Hz}$ frequency. Some variations may occur, including the supplied discharge power and the speed, which can reach a maximum of $1.5 \mathrm{~kW}$ and a speed of $60 \mathrm{~m} \mathrm{~min}^{-1}$. The optimized parameters used were $1 \mathrm{~kW}$ of power and a velocity of $4 \mathrm{~m} \mathrm{~min}^{-1}$ with 5 passages corresponding to a dosage of $2.5 \mathrm{kWmin}^{-2}$, as previously reported [22]. A pre-washed sample is simply passed through the plasma lamina 5 times, in both sides, to obtain the desired dosage. A significant increase in the oxygen content due to the incorporation of oxygen atoms onto the fabric surface is usually observed after plasma treatment. Plasma etching may provoke some scission in the $\mathrm{C}-\mathrm{H}, \mathrm{C}-\mathrm{O}, \mathrm{C}-\mathrm{N}, \mathrm{C}-\mathrm{C}$ and $\mathrm{N}-\mathrm{H}$ bonds present in the fibers, leading to the formation of reactive $\mathrm{O}^{-}, \mathrm{N}, \mathrm{N}^{+}, \mathrm{O}, \mathrm{OH}^{-}$ and $\mathrm{O}^{3}$ species [23]. In addition, plasma treatment also induces notable morphological alterations on the fibers' surface, augmenting the roughness and thus increasing surface energy, wettability and adhesion [24].

\subsection{Functionalization of Nylon Fabric with Antimicrobial Agents}

Nylon fabrics were coated with chitosan, AgNPs and a mixture of both, using different concentrations of mixed solutions, as described in Figure 1. Dilutions were made starting with the mother solution of chitosan $(\mathrm{CH})$ and AgNPs $(\mathrm{Ag})$ with the following percentage ratio of $\mathrm{CH} / \mathrm{Ag}:$ 100:0, 0:100, 60:40, 70:03, 80:20 and 90:10 (Figure 1A). The coating solution was applied to the polyamide fabric by a simple dip-coating technique. The fabric was dipped in each solution for $5 \mathrm{~min}$, at room temperature (Figure 1B). The coated material was incubated in an oven, at $50^{\circ} \mathrm{C}$, for $20 \mathrm{~min}$.
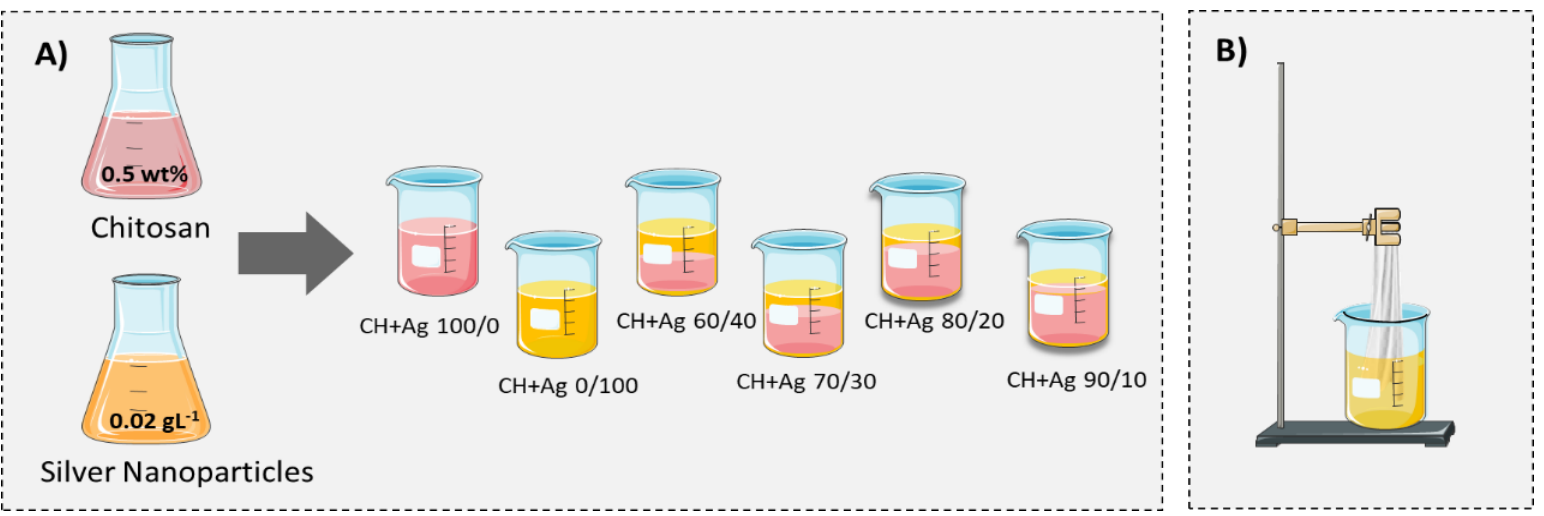

Figure 1. Schematic representation of (A) the solutions for coating the nylon fabric; dilutions were made with the mother solution of chitosan $(\mathrm{CH})$ and silver nanoparticles $(\mathrm{Ag})$, and $(\mathbf{B})$ dip-coating method used for the coating. The dilutions are represented as the percentage of chitosan and silver $(\mathrm{CH} / \mathrm{Ag})$.

\subsection{Scanning Electron Microscopic (SEM) Analysis}

The morphological characterization of AgNPs and the combination of both AgNPs with chitosan were visualized by SEM, which was also used to assess the mean particle 
average of the obtained NPs. Further, the functionalized nylon fabrics with both antimicrobial agents before and after application of plasma treatment were also visualized with SEM. An ultra-high resolution Field Emission Gun-Scanning Electron Microscopy (FEG-SEM), NOVA 200 Nano SEM, FEI Company (Hillsboro, Oregon, EUA) was used. Secondary electron and backscattering electron images were performed with an acceleration voltage of 5 and $15 \mathrm{kV}$, respectively. Samples were previously coated with an Au-Pd film (80-20 weight \%) in a high-resolution sputter coater, 208HR Cressington Company (Watford, England), coupled to an MTM-20 Cressington High-Resolution Thickness Controller, to reduce the possibility of oxidation during processing. A turbo pump was used to obtain a higher (and cleaner) vacuum environment. To remove air and increase sputter efficiency, pure argon gas was backfilled into the chamber. When high-magnification images are required, $\mathrm{Au}$ alone is not recommended as a sputter coating. The recommended metal coatings for general research purpose is gold/palladium sputtered alloy $(80 / 20)$, due to its having a smaller grain size than $\mathrm{Au}$. The Pd L-series X-ray lines at $2.84 \mathrm{keV}$ do not overlap important lines from other elements; thus, no additional interference with X-ray microanalysis would be expected besides the one mentioned for Au.

The prepared silver colloid suspension was released in copper grids with carbon film 400 meshes, $3 \mathrm{~mm}$ diameter for STEM nanoparticle analysis. The mean size was extrapolated by measuring the average diameter based in 50 observations.

\subsection{UV-Vis Reflectance and Adsorption Measures}

UV-visible absorption intensity employing diffuse reflectance spectrophotometer (Spectraflash 600, Datacolor, Lawrenceville, NJ, USA) at standard illuminant D65 (LAV/Spec. Excl., $\mathrm{d} / 8, \mathrm{D} 65 / 10^{\circ}$ ) was used to monitor the changes associated with modification of nylon fabric with silver nanoparticles in the wavelength range of $200-800 \mathrm{~nm}$, at room temperature. The results were expressed as the values of reflectance percentage at the peak of maximum adsorption of the AgNPs. The peak of the maximum adsorption of the AgNPs in the aqueous colloidal solution, determined at $410 \mathrm{~nm}$ and characteristic of silver surface plasmon resonance (SPR), was measured in a UV-Vis spectrophotometer (Shimadzu, Kyoto, Japan, UV-1800) with quartz cuvettes (Figure 2C).

\subsection{X-ray Photoelectron Spectroscopy (XPS)}

XPS was performed in a Kratos AXIS Ultra HAS (Kratos Analytical Limited, Manchester, UK), using a VISION software (Vision 2, Kratos Analytical Limited, Manchester, UK) for data acquisition. The acquired data were analyzed by using the CASAXPS software (casaXPS 2.3.22. Casa Software Ltd., Teignmouth, UK). A monochromatic Al K $\alpha$ X-ray source $(1486.7 \mathrm{eV})$, operating at $15 \mathrm{kV}(150 \mathrm{~W})$, in FAT (Fixed Analyzer Transmission) mode, was used, with a pass energy of $40 \mathrm{eV}$ for regions ROI and $80 \mathrm{eV}$ for survey. For data acquisition, a pressure lower than 10-6 Pa was applied, and a charge neutralization system was used. To obtain the s $\mathrm{C} 1$ s spectral component (C-C. C-H) with a binding energy of $285 \mathrm{eV}$, the spectra were corrected, and a high-resolution spectrum of Ag was collected on $\mathrm{a} \approx 1 \mathrm{~mm}^{2}$ piece of polyamide fabric coated with only silver (without chitosan). A process to obtain a peak with equal FWHM (Full Width at Half Maximum) to the main peak was applied, inducing an error of approximately $\pm 0.1 \mathrm{eV}$.

\subsection{Antimicrobial Assays}

The antimicrobial activity was determined by using the standard shake flask method (ASTM-E2149-01), with some modifications. Staphylococcus aureus (ATCC25923) (S. aureus) and Pseudomonas aeruginosa (PAO1) (P. aeruginosa) inoculum were prepared by using a single colony from the corresponding bacterial. The culture was grown overnight in sterile nutrient broth (NB, Sharlab, Spain), at $37^{\circ} \mathrm{C}$ and $230 \mathrm{rpm}$. The material was incubated with $5 \mathrm{~mL}$ of bacterial suspension ( $3 \mathrm{E} 8 \mathrm{cell} / \mathrm{mL}$ in $\mathrm{NaCl} 0.9 \% \mathrm{pH} 6.5$ ), at $37^{\circ} \mathrm{C}$ and $100 \mathrm{rpm}$, for $2 \mathrm{~h}$. After the suspensions were withdrawn, the bacteria viability was determined by flow cytometry, as described below. 

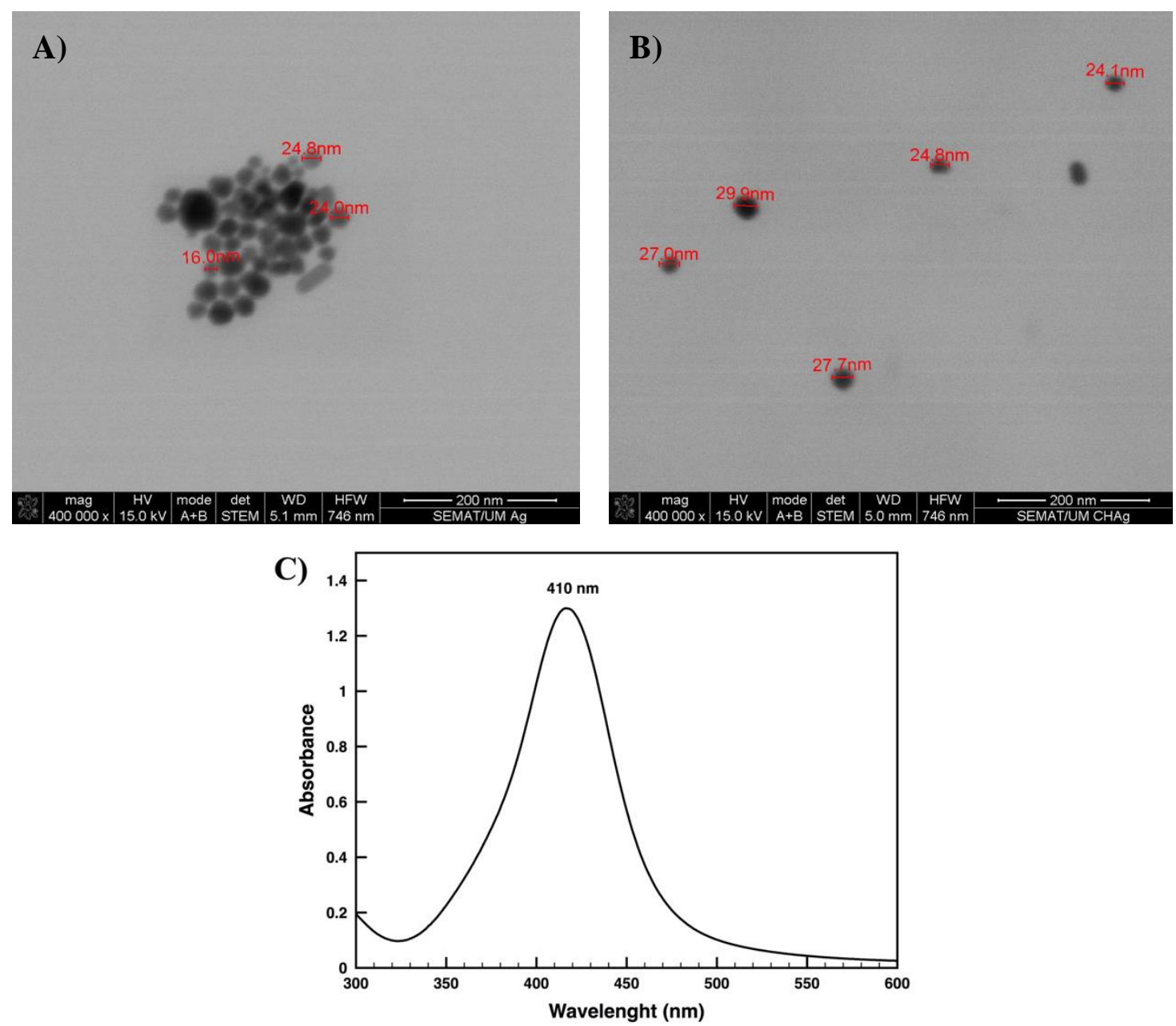

Figure 2. STEM images of the AgNPs aqueous colloidal solution depicting the synthesized silver nanoparticles in the absence (A) and the presence (B) of chitosan and (C) UV-Vis spectra of the AgNPs aqueous colloidal solution.

\subsection{Flow Cytometry}

Viability Staining Protocol: To assess bacterial viability, SYTO-BC (Molecular Probes Eugene, OR) and propidium iodide (PI) (Sigma-Aldrich, St. Louis, MO, USA) were used, according to manufacturer's instructions.

A volume of $2.5 \mu \mathrm{L}$ and $10 \mu \mathrm{L}$ of the SYTO-BC ( $50 \mu \mathrm{M}$ stock solution) mixed with $5 \mu \mathrm{L}$ of PI ( $1.5 \mathrm{mM}$ stock solution) was added to $250 \mu \mathrm{L}$ of bacterial suspension of $S$. aureus and P. aeruginosa, respectively. Samples were analyzed after at least $15 \mathrm{~min}$ of incubation at room temperature. Cell debris and other particles were excluded by gating as unstained particles.

Setting parameters and data analysis: Live/dead bacteria were assessed, using a EC800 Flow Cytometry Analyzer (Sony Biotechnology Inc., Champaign, IL, USA). SYTO$\mathrm{BC}$ and PI were excited by a diode blue laser $(488 \mathrm{~nm})$. The green fluorescence emitted by bacteria with intact membrane, here designed as "live", was detected by using a 530/50 nm bandpass, and the red fluorescence emitted by bacteria with damaged membrane, here designed as "dead", was detected by using a 615/30 nm bandpass filter. Therefore, for convenience of the data analysis, double-stained bacteria corresponding to "compromised bacteria" were considered as "dead". The logarithmic mode was used to amplify the fluorescence signal. The flow rate used to analyze a sample volume of $100 \mu \mathrm{L}$ was $10 \mu \mathrm{L} / \mathrm{min}$, and a total of 40,000 cells were counted. All the samples were run in triplicate, for reproducibility of the experiment. EC800 software version 1.3.6. (Sony Biotechnology Inc., Champaign, IL, USA) was used for data analysis. 


\section{Results and Discussion}

In this work, the synthesis of AgNPs was performed by using a well-known chemical procedure described by Lee and Meisel [21], which usually results in NPs colloidal solution that is cytotoxic in contact with mammalian cells $[25,26]$. The combination of AgNPs on a polymeric matrix results in the improvement of the biocompatibility, without jeopardizing the antimicrobial effect of the NPs $[27,28]$. That is why a nanoformulation containing chitosan solution with dispersed AgNPs to further apply on the nylon fabrics was developed. The chitosan solution was found to act as a stabilizer and dispersant of the AgNPs. As depicted in Figure 2, the AgNPs agglomerate when observed in STEM from the aqueous colloidal solution (Figure 2A), while in the presence of chitosan, they are well dispersed, keeping an average size of $24.8 \pm 4.1 \mathrm{~nm}$ (Figure 2B). The colloidal citrate solution of synthetized AgNPs has a very low aggregation and remains stable for two months, in a refrigerator. However, due to the vacuum condition of SEM analysis (and also in the fabric during deposition), the drying effect promotes aggregation of the AgNPs. This effect is significantly lowered after the addition of chitosan that seems to act as a surfactant for the stabilization of the NPs. This is very important in terms of biomedical applications. Chitosan, besides acting as a surfactant, also possesses important antimicrobial properties. The charged amino group present in its chemical structure confers a biodegradable and biocompatible character to the mixture [27].

The AgNPs, chitosan and the mixture of both were impregnated in the nylon fabrics, through a dip-coating method, on the material with and without a previous plasma treatment. Figure 3 shows the surface of the textile material. It could be observed that the plasma-treated nylon control has a smoother surface, which is the result of a surface etching induced by the application of plasma, whose rate depends on the degree of crystallinity of the material [29]. Overall, the application of all types of antimicrobial agents (AgNPs, chitosan and the combination of both) is clearly influenced by the plasma treatment. The plasma-treated material has a higher amount of coating material on its surface, although it is not fully covered by any of the materials. The layers are more prominent on plasma-treated samples (Figure 3, right column). As expected, when the AgNPs are applied without the chitosan, they agglomerate in one part of the fiber; meanwhile, when applied together with the chitosan, a layer of this combined coating is clearly observed (Figure 3, last line).

The nylon fabric was further tested for incorporation of increased concentration of silver on the chitosan-based nanoformulations. Reflectance measurements were performed to qualitatively assess the amount of silver immobilized on the material surface. The reflectance was measured at the higher observed peak for Ag NPs (410 nm) assigned to the silver surface plasmon resonance usually located in between 405 and $425 \mathrm{~nm}$ [30-32]. The lower the reflectance the higher is the amount of Ag in the material surface. Thus, the decrease observed in Figure 4 on the reflectance at $410 \mathrm{~nm}$ indicates an increase of the NPs incorporation on the material surface mainly on the material previously treated with plasma at a concentration ratio of $60 / 40$ or when only $\mathrm{Ag}$ was present $(\mathrm{PA}+\mathrm{CH}+\mathrm{Ag} 0 / 100)$. In fact, a significant decrease was observed when the highest concentrations of AgNPs were incorporated after plasma treatment, indicating that the improved adhesion in the presence of plasma is driven by a concentration-related mechanism (Figure 4).

Figure 5 presents the high-resolution XPS spectrum for Ag3d. As expected, the spectrum shows spin-orbit split $3 \mathrm{~d}_{5 / 2}$ and $3 \mathrm{~d}_{3 / 2}$ components separated by $6 \mathrm{eV}$ [33]. $\mathrm{Ag} 3 \mathrm{~d}_{5 / 2}$ and $3 \mathrm{~d}_{3 / 2}$ binding energies are centered approximately at $368.3 \pm 0.3 \mathrm{eV}$ and $374.3 \pm 0.3 \mathrm{eV}$, respectively. This is in good agreement with the metallic state of $\mathrm{Ag}\left(\mathrm{Ag}^{0}\right)$ on textiles [34,35]. The rather narrow FWHM of Ag3d5/2 indicates a narrow size distribution of the nanoparticles, which is consistent with the STEM results in Figure 2 [36]. 


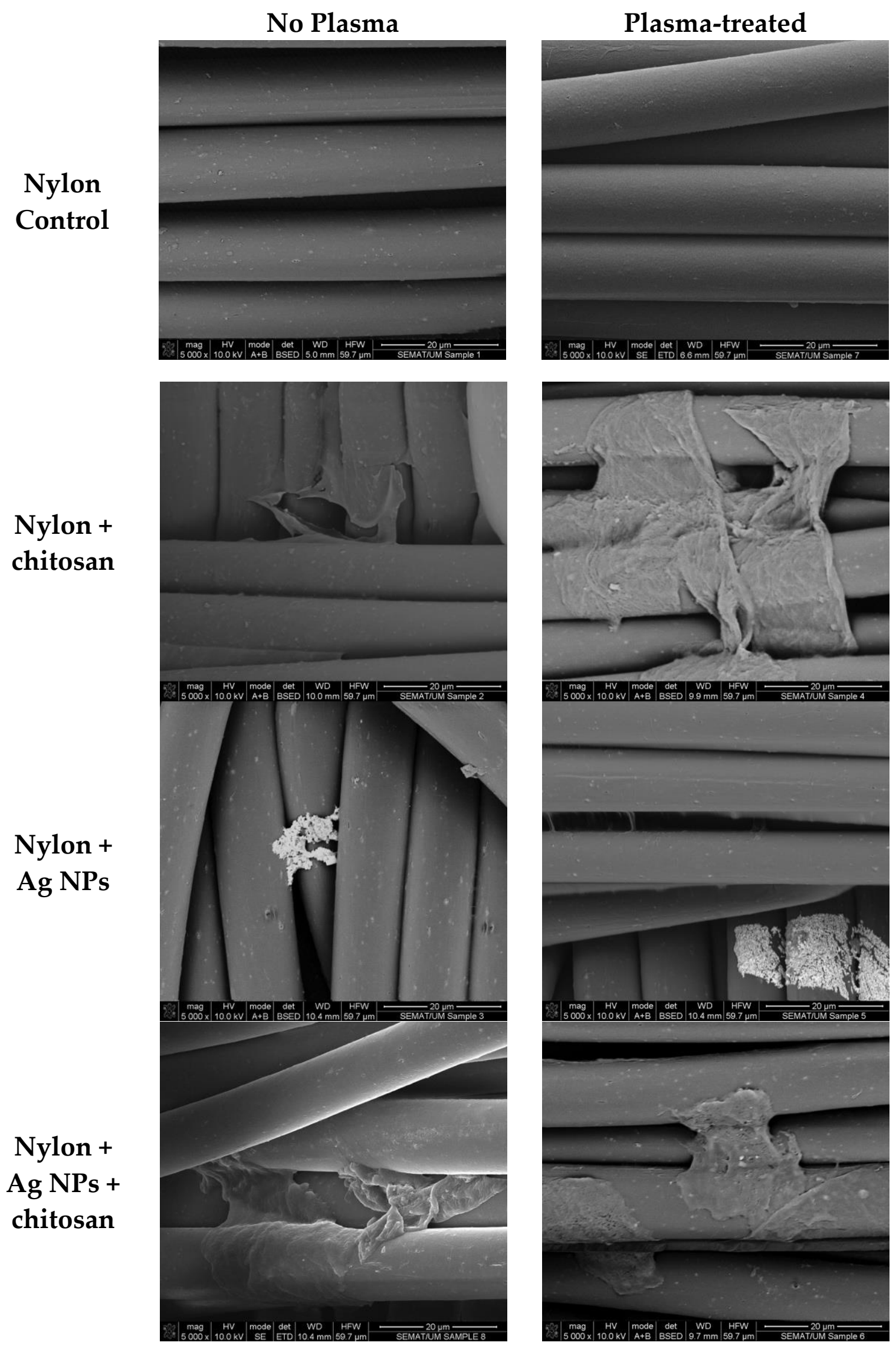

Figure 3. SEM images of the surface of nylon fabrics before (left column) and after (right column) plasma treatment. The lines depict the surface of the nylon textile prior to the functionalization (control), functionalized with chitosan (Nylon + chitosan), with Ag NPs (Nylon + Ag NPs) and with both antimicrobial agents (Nylon + Ag NPs + chitosan). 


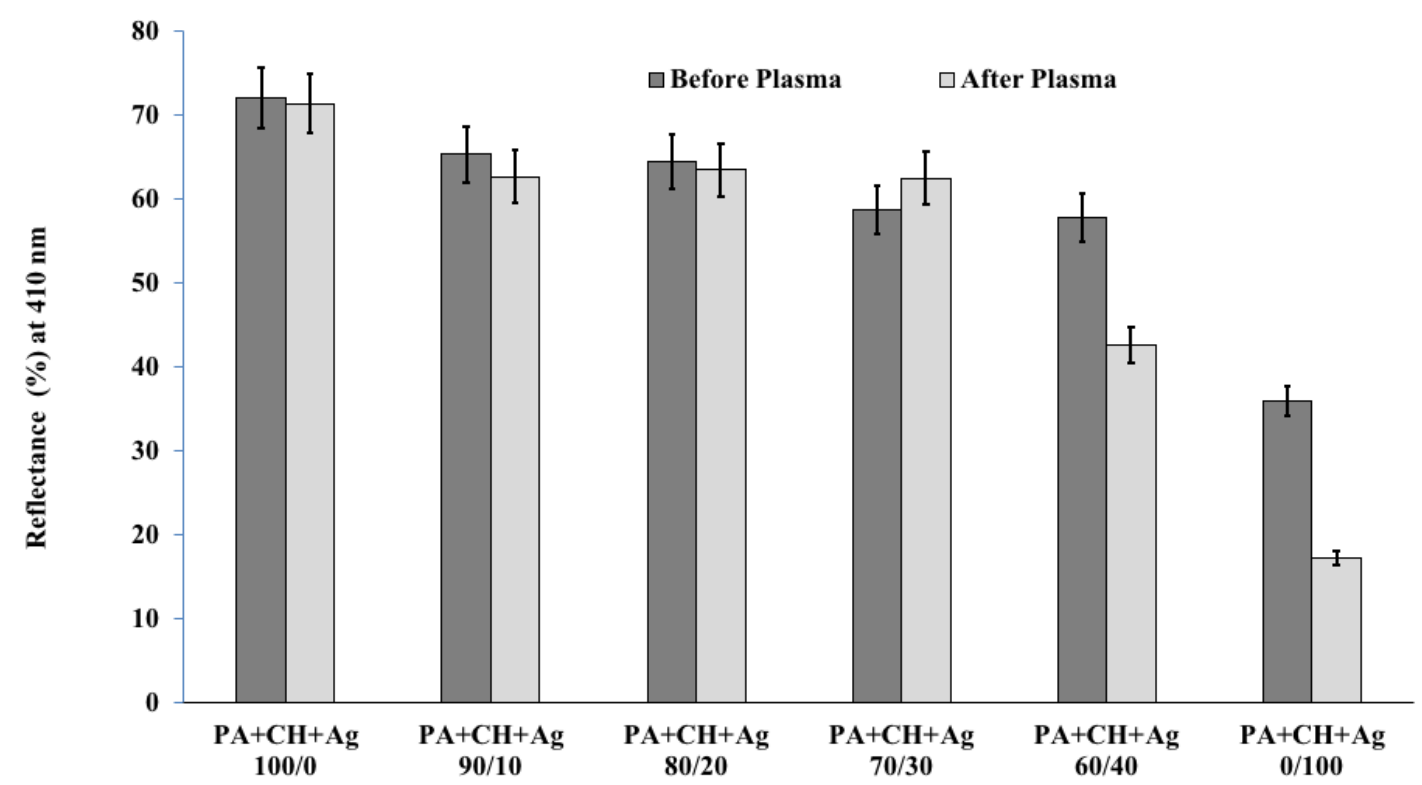

Figure 4. UV-Vis reflectance spectroscopy measurements of nylon fabric at $410 \mathrm{~nm}$ with increasing concentration of silver on non-treated and treated plasma nylon fabrics (PA-Nylon fabric; $\mathrm{CH}-\mathrm{Chitosan;} \mathrm{Ag}-$ Silver nanoparticles). The dilutions are represented as the percentage of chitosan and silver $(\mathrm{CH} / \mathrm{Ag})$, where the sample $\mathrm{PA}+\mathrm{CH}+\mathrm{Ag} 100 / 0$ represents the control only with chitosan, and the $\mathrm{PA}+\mathrm{CH}+\mathrm{Ag} 0 / 100$ represents the control only with AgNPs.

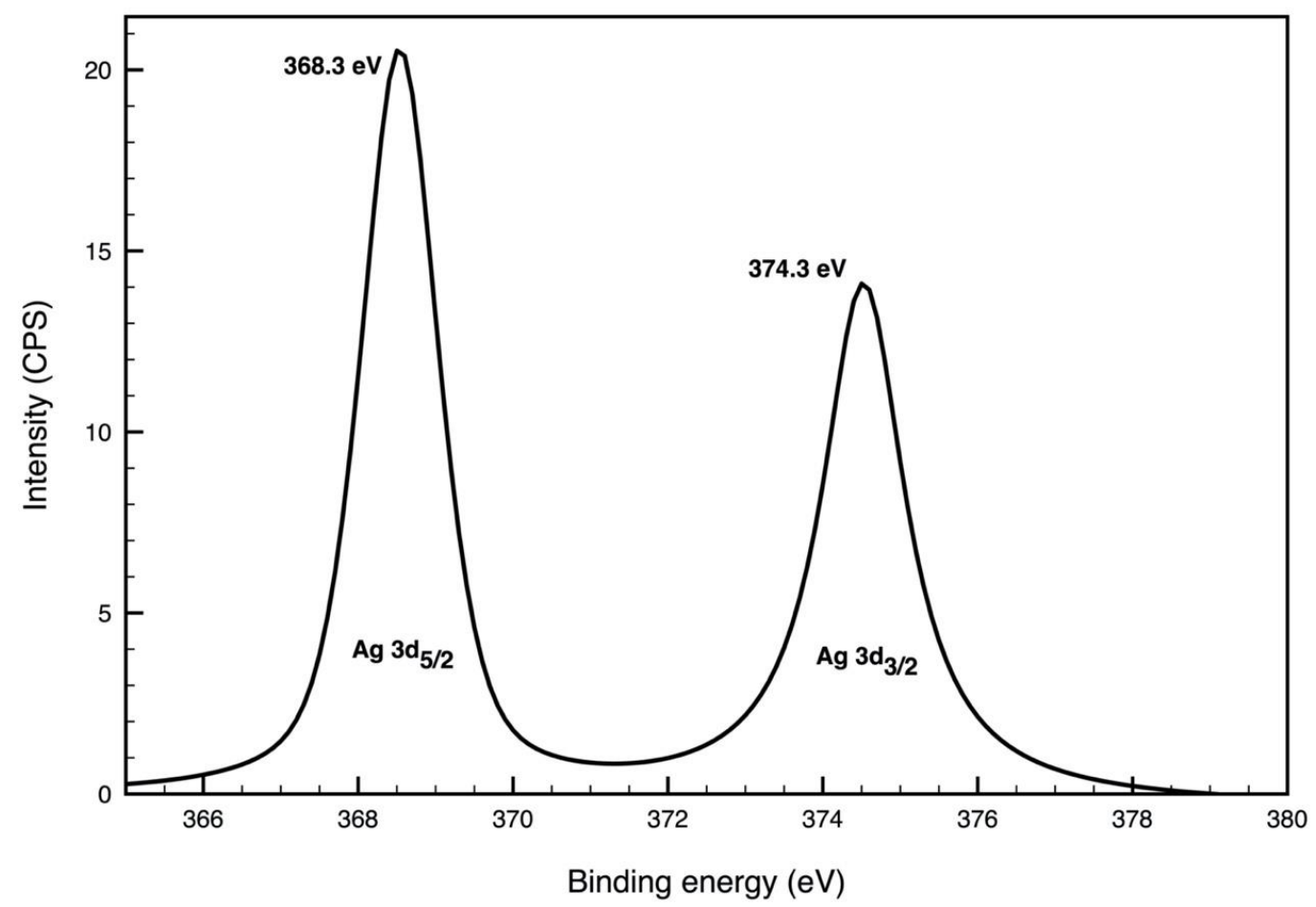

Figure 5. High-resolution XPS spectrum of the Ag3d envelope of plasma-treated PA nylon fabric with deposited AgNPs $(\mathrm{PA}+\mathrm{CH}+\mathrm{Ag} 0 / 100)$.

The antimicrobial property of the nylon fabric (PA) was further assessed by taking into account different combinations of chitosan $(\mathrm{CH})$ and AgNPs. Overall, different antimicrobial responses were obtained for a Gram-positive bacterium (S. aureus) and for a Gram-negative bacterium (P. aeruginosa) (Figure 6). The bactericidal activity was higher 
for the S. aureus than for P. aeruginosa in all the combinations of chitosan and AgNPs. The percentage of $S$. aureus $\mathrm{CFU}$ was reduced to less than $20 \%$ when exposed to each of the combinations of chitosan and AgNPs; the fabric with percentage of chitosan and AgNPs $70 / 30$ was the most effective. P. aeruginosa was less susceptible to the antimicrobial treatment; the treatment with only NPs $(0 / 100)$ was ineffective. The combination of chitosan with AgNPs resulted in $60 \%$ reduction of $P$. aeruginosa, approximately. In order to evaluate the possibility of this material to be reused, the fabric was subjected to a washing treatment, after which the percentage of live bacteria increased significantly $(p<0.001)$ for all the combinations of chitosan and AgNPs. This result indicates that the chitosan and AgNPs coating is unstable, being almost completely removed from the fabrics after washing, as shown Figure 6.

(A) Staphylococcus aureus
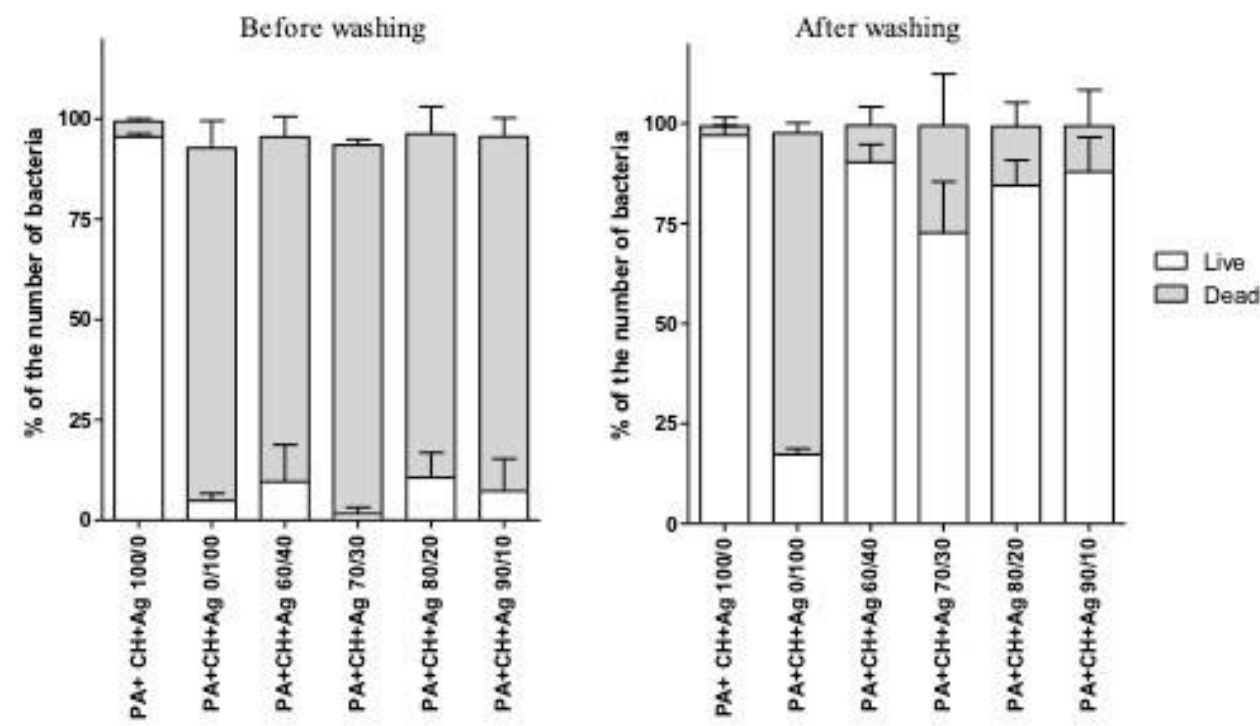

(B) Pseudomonas aeruginosa
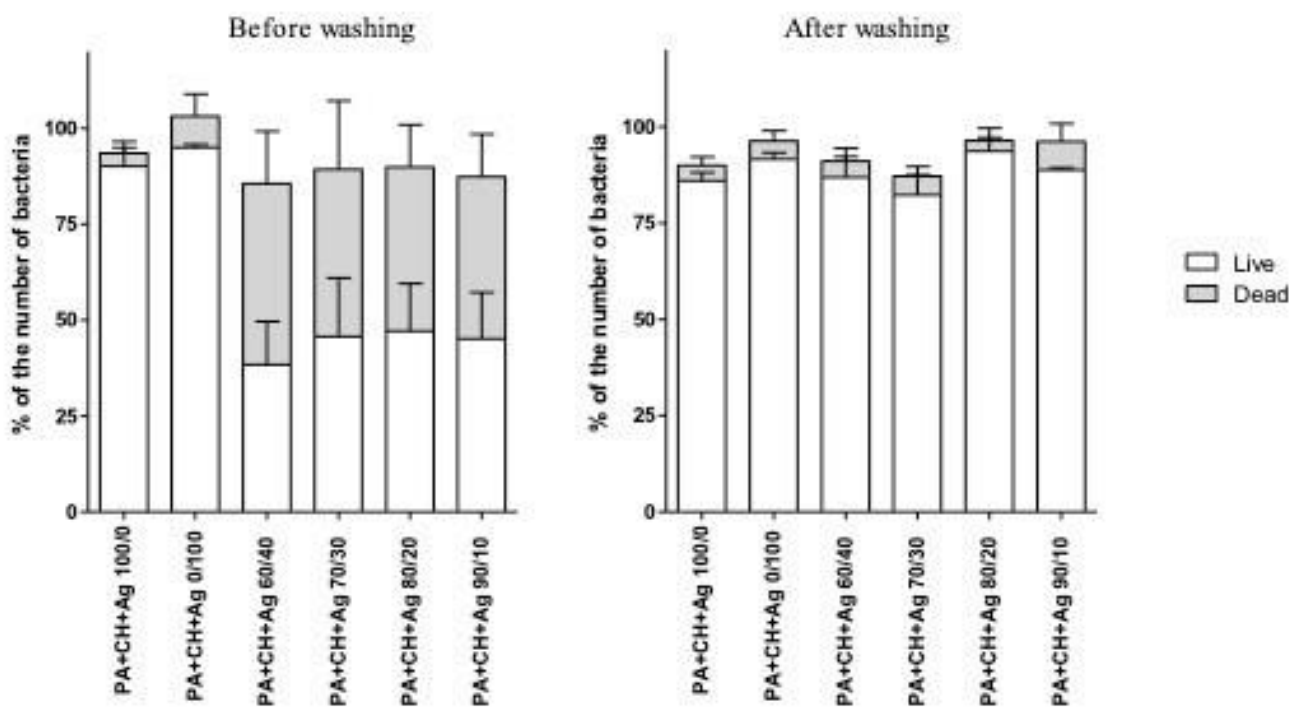

Figure 6. Antimicrobial response of Staphylococcus aureus (A) and Pseudomonas aeruginosa (B) to different combinations of chitosan $(\mathrm{CH})$ and silver nanoparticles $(\mathrm{Ag})$, before and after washing of the nylon fabrics $(\mathrm{PA})$. The dilutions are represented as the percentage of chitosan and silver $(\mathrm{CH} / \mathrm{Ag})$, where the sample $\mathrm{PA}+\mathrm{CH}+\mathrm{Ag} \mathrm{100/0}$ represents the control only with chitosan and the PA $+\mathrm{CH}+\mathrm{Ag}$ 0/100 represents the control only with AgNPs. 
The two bacteria tested, $S$. aureus and P. aeruginosa, are among the most common infection agents and representative of each group (Gram-positive and Gram-negative bacteria, respectively). As these bacteria are often found in skin and the upper respiratory tract, they will pose a serious problem in the use of facial masks, as fabric is in contact with skin for many hours. The infections caused by these two infectious agents can be minor to life-threatening, being particularly dangerous for immunocompromised patients [37-39].

P. aeruginosa is a Gram-negative bacillus characterized by a cytoplasmatic membrane with a symmetric phospholipid bilayer and asymmetric outer membrane with a phospholipid inner face and a lipopolysaccharide outer layer forming a permeability barrier $[40,41]$. In the presence of AgNPs, the first event is the adsorption of AgNPs into the surface of the cell membrane. This will undermine the membrane integrity, inducing the particles transport into the cytoplasm influencing several metabolic processes. It has been reported that AgNPs influence the equilibrium of the oxidation and anti-oxidation mechanisms, leading to an excess of reactive oxygen species, which can cause DNA aggregation and protein degradation, leading to the cell death [42-44]. This process, described by Liao et al., can take up to several hours; in our case, the bacterium was only in contact with the nanoparticles for $2 \mathrm{~h}$, which may indicate that that was not enough contact time to obtain a higher death rate.

An important difference between Gram-negative and Gram-positive bacteria is the composition of the cell wall, which may justify the distinct effects observed on the presence of the AgNPs [45].

A Gram-positive bacterium does not have an outer membrane, similar to the Gramnegative bacterium, but has a thick layer of peptidoglycan complemented by anionic glycopolymers know as teichoic acids [46]. This structure is known to offer less resistance to the passage of some substances, like antibiotics, and it has been claimed that silver can perforate the peptidoglycan cell wall [2-4,47,48] (Figure 7).

\section{Gram-negative Bacteria}
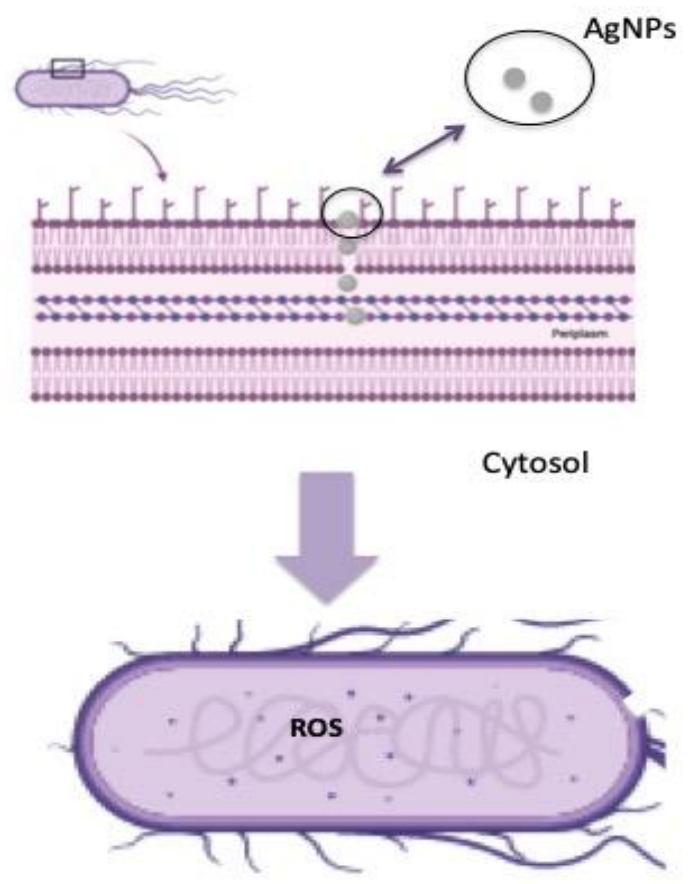

\section{Gram-positive Bacteria}

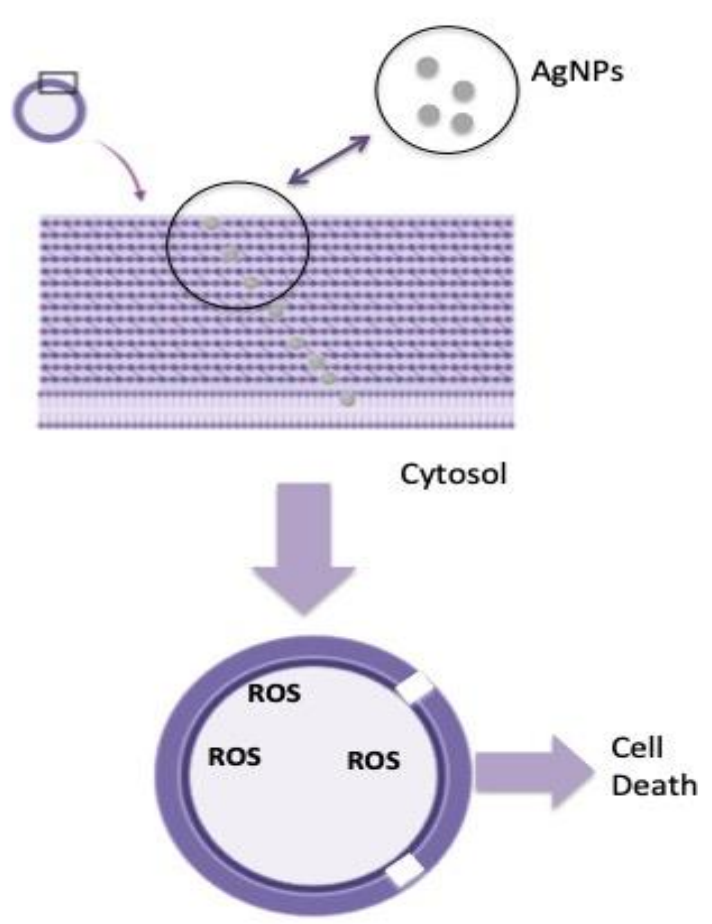

Figure 7. Schematic representation of the antimicrobial mechanism proposed (Created with BioRender.com). 


\section{Conclusions}

This work demonstrated that, by simply using well-known antimicrobial agents such as chitosan and AgNPs, combined over a commonly used fabric such as nylon, we may obtain an antimicrobial textile suitable to be used as a face mask. The synergy between the chitosan and the AgNPs allowed for obtaining an antimicrobial coating with little amount of silver, which is a breakthrough if we considered silver toxicity. The developed synergistic coating demonstrated itself to be highly effective against the most common Gram-positive (S. aureus) and Gram-negative (P. aeruginosa) bacteria, highly decreasing their live count by approximately $80 \%$ and $60 \%$, respectively, after $2 \mathrm{~h}$. Even though the coating seems to be unstable after a washing treatment, this can be applied in the external side of facial mask fabrics, as it will prevent virus and bacteria accumulation onto the fibers. According to the literature, the presence of silver in this form may also prevent cross-contamination infections by SARS-COV-2 virus. To our knowledge, the coating of nylon fabrics intended for face masks' material with both agents has never been reported. The new-coated fabric can be successfully used for a single-use facemask.

Author Contributions: Conceptualization, J.M.S., R.F. and A.Z.; methodology, J.M.S., A.Z., M.M.F., C.M.B. and A.M.S.; formal analysis, J.M.S., C.M.B. and N.D.; investigation, J.M.S. and C.M.B.; writing—original draft preparation, J.M.S., C.M.B., A.Z. and M.M.F.; writing—review and editing, C.M.B., A.Z. and M.M.F.; supervision, J.A.T., R.F. and A.Z. All authors have read and agreed to the published version of the manuscript.

Funding: This study was supported by the Portuguese Foundation for Science and Technology (FCT), under the scope of the strategic funding of UIDB/04469/2020 unit, and BioTecNorte operation (NORTE-01-0145-FEDER-000004). funded by the European Regional Development, Fund under the scope of Norte2020—Programa Operacional Regional do Norte.

Acknowledgments: This study was supported by the Portuguese Foundation for Science and Technology (FCT), under the scope of the strategic funding of UIDB/04469/2020 unit, and BioTecNorte operation (NORTE-01-0145-FEDER-000004), funded by the European Regional Development Fund, under the scope of Norte2020-Programa Operacional Regional do Norte.

Conflicts of Interest: The authors declare no conflict of interest.

\section{References}

1. Bahadar, H.; Maqbool, F.; Niaz, K.; Abdollahi, M. Toxicity of Nanoparticles and an Overview of Current Experimental Models. Iran. Biomed. J. 2016, 20, 1-11. [CrossRef] [PubMed]

2. Cheng, L.; Zhang, K.; Zhang, N.; Melo, M.A.S.; Weir, M.D.; Zhou, X.D.; Bai, Y.X.; Reynolds, M.A.; Xu, H.H.K. Developing a New Generation of Antimicrobial and Bioactive Dental Resins. J. Dent. Res. 2017, 96, 855-863. [CrossRef] [PubMed]

3. Cinteza, L.O.; Scomoroscenco, C.; Voicu, S.N.; Nistor, C.L.; Nitu, S.G.; Trica, B.; Jecu, M.-L.; Petcu, C. Chitosan-Stabilized Ag Nanoparticles with Superior Biocompatibility and Their Synergistic Antibacterial Effect in Mixtures with Essential Oils. Nanomaterials 2018, 8, 826. [CrossRef] [PubMed]

4. Regiel-Futyra, A.; Kus-Liśkiewicz, M.; Sebastian, V.; Irusta, S.; Arruebo, M.; Kyzioł, A.; Stochel, G. Development of noncytotoxic silver-chitosan nanocomposites for efficient control of biofilm forming microbes. RSC Adv. 2017, 7, 52398-52413. [CrossRef]

5. Elechiguerra, J.L.; Burt, J.L.; Morones, J.R.; Camacho-Bragado, A.; Gao, X.; Lara, H.H.; Yacaman, M.J. Interaction of silver nanoparticles with HIV-1. J. Nanobiotechnol. 2005, 3, 6. [CrossRef] [PubMed]

6. Sun, R.W.; Chen, R.; Chung, N.P.; Ho, C.M.; Lin, C.L.; Che, C.M. Silver nanoparticles fabricated in Hepes buffer exhibit cytoprotective activities toward HIV-1 infected cells. Chem. Commun. 2005, 5059-5061. [CrossRef]

7. Lu, L.; Sun, R.W.; Chen, R.; Hui, C.K.; Ho, C.M.; Luk, J.M.; Lau, G.K.; Che, C.M. Silver nanoparticles inhibit hepatitis B virus replication. Antivir. Ther. 2008, 13, 253-262.

8. Baram-Pinto, D.; Shukla, S.; Perkas, N.; Gedanken, A.; Sarid, R. Inhibition of Herpes Simplex Virus Type 1 Infection by Silver Nanoparticles Capped with Mercaptoethane Sulfonate. Bioconjug. Chem. 2009, 20, 1497-1502. [CrossRef]

9. Sun, L.; Singh, A.; Vig, K.; Pillai, S.; Singh, S. Silver Nanoparticles Inhibit Replication of Respiratory Syncytial Virus. J. Biomed. Nanotechnol. 2008, 4, 149-158.

10. Rogers, J.V.; Parkinson, C.V.; Choi, Y.W.; Speshock, J.L.; Hussain, S.M. A Preliminary Assessment of Silver Nanoparticle Inhibition of Monkeypox Virus Plaque Formation. Nanoscale Res. Lett. 2008, 3, 129-133. [CrossRef]

11. Xiang, D.X.; Chen, Q.; Pang, L.; Zheng, C.L. Inhibitory effects of silver nanoparticles on H1N1 influenza A virus in vitro. J. Virol. Methods 2011, 178, 137-142. [CrossRef] [PubMed] 
12. Zachar, O. Formulations for COVID-19 Treatment via Silver Nanoparticles Inhalation Delivery at Home and Hospital. ScienceOpen Preprints 2020, 1. [CrossRef]

13. Ivanova, A.A.; Surmenev, R.A.; Surmeneva, M.A.; Mukhametkaliyev, T.; Loza, K.; Prymak, O.; Epple, M. Hybrid biocomposite with a tunable antibacterial activity and bioactivity based on RF magnetron sputter deposited coating and silver nanoparticles. Appl. Surf. Sci. 2015, 329, 212-218. [CrossRef]

14. Alissawi, N.; Peter, T.; Strunskus, T.; Ebbert, C.; Grundmeier, G.; Faupel, F. Plasma-polymerized HMDSO coatings to adjust the silver ion release properties of Ag/polymer nanocomposites. J. Nanopart. Res. 2013, 15. [CrossRef]

15. Pappas, D. Status and potential of atmospheric plasma processing of materials. J. Vac. Sci. Technol. A 2011, 29, 020801. [CrossRef]

16. Jia, C.X.; Chen, P.; Liu, W.; Li, B.; Wang, Q.A. Surface treatment of aramid fiber by air dielectric barrier discharge plasma at atmospheric pressure. Applied Surface Science 2011, 257, 4165-4170. [CrossRef]

17. Radić, N.; Obradović, B.M.; Kostić, M.; Dojčinović, B.; Kuraica, M.M.; Černák, M. Deposition of silver ions onto DBD and DCSBD plasma treated nonwoven polypropylene. Surf. Coat. Technol. 2012, 206, 5006-5011. [CrossRef]

18. Zille, A.; Oliveira, F.R.; Souto, A.P. Plasma Treatment in Textile Industry. Plasma Process. Polym. 2015, 12, 98-131. [CrossRef]

19. Hosne Asif, A.K.M.A.; Hasan, M.Z. Application of Nanotechnology in Modern Textiles: A Review. Int. J. Curr. Eng. Technol. 2018, 8. [CrossRef]

20. Mei, L.; Xu, Z.; Shi, Y.; Lin, C.; Jiao, S.; Zhang, L.; Li, P. Multivalent and synergistic chitosan oligosaccharide-Ag nanocomposites for therapy of bacterial infection. Sci. Rep. 2020, 10, 1-9. [CrossRef]

21. Lee, P.C.; Meisel, D. Adsorption and surface-enhanced Raman of dyes on silver and gold sols. J. Phys. Chem. 1982, 86, 3391-3395. [CrossRef]

22. Oliveira, F.; Souto, A.; Carneiro, N.; Oliveira, H. Surface Modification on Polyamide 6.6 with Double Barrier Discharge (DBD) Plasma to Optimise Dyeing Process by Direct Dyes. Mater. Sci. Forum 2010, 636-637, 846-852. [CrossRef]

23. Zille, A.; Fernandes, M.M.; Francesko, A.; Tzanov, T.; Fernandes, M.; Oliveira, F.R.; Almeida, L.; Amorim, T.; Carneiro, N.; Esteves, M.F.; et al. Size and Aging Effects on Antimicrobial Efficiency of Silver Nanoparticles Coated on Polyamide Fabrics Activated by Atmospheric DBD Plasma. ACS Appl. Mater. Interfaces 2015, 7, 13731-13744. [CrossRef] [PubMed]

24. Oliveira, F.R.; Zille, A.; Souto, A.P. Dyeing mechanism and optimization of polyamide 6,6 functionalized with double barrier discharge (DBD) plasma in air. Appl. Surf. Sci. 2014, 293, 177-186. [CrossRef]

25. Wang, L.-S.; Wang, C.-Y.; Yang, C.-H.; Hsieh, C.-L.; Chen, S.-Y.; Shen, C.-Y.; Wang, J.-J.; Huang, K.-S. Synthesis and anti-fungal effect of silver nanoparticles-chitosan composite particles. Int. J. Nanomed. 2015, 10, 2685-2696. [CrossRef]

26. Sambale, F.; Wagner, S.; Stahl, F.; Khaydarov, R.R.; Scheper, T.; Bahnemann, D. Investigations of the Toxic Effect of Silver Nanoparticles on Mammalian Cell Lines. J. Nanomater. 2015, 2015, 136765. [CrossRef]

27. Regiel, A.; Irusta, S.; Kyzioł, A.; Arruebo, M.; Santamaria, J. Preparation and characterization of chitosan-silver nanocomposite films and their antibacterial activity against Staphylococcus aureus. Nanotechnology 2013, 24, 015101. [CrossRef]

28. Pakseresht, S.; Alogaili, A.W.M.; Akbulut, H.; Placha, D.; Pazdziora, E.; Klushina, D.; Konvičková, Z.; Kratošová, G.; Holešová, S.; Martynková, G.S. Silver/Chitosan Antimicrobial Nanocomposites Coating for Medical Devices: Comparison of Nanofiller Effect Prepared via Chemical Reduction and Biosynthesis. J. Nanosci. Nanotechnol. 2019, 19, 2938-2942. [CrossRef]

29. Neděla, O.; Slepička, P.; Švorčík, V. Surface Modification of Polymer Substrates for Biomedical Applications. Materials 2017, 10, 1115. [CrossRef]

30. Khodashenas, B.; Ghorbani, H.R. Synthesis of silver nanoparticles with different shapes. Arab. J. Chem. 2019, 12, 1823-1838. [CrossRef]

31. Carré-Rangel, L.; Alonso-Nuñez, G.; Espinoza-Gómez, H.; Flores-López, L.Z. Green Synthesis of Silver Nanoparticles: Effect of Dextran Molecular Weight Used as Stabilizing-Reducing Agent. J. Nanosci. Nanotechnol. 2015, 15, 9849-9855. [CrossRef] [PubMed]

32. Bankura, K.P.; Maity, D.; Mollick, M.M.R.; Mondal, D.; Bhowmick, B.; Bain, M.K.; Chakraborty, A.; Sarkar, J.; Acharya, K.; Chattopadhyay, D. Synthesis, characterization and antimicrobial activity of dextran stabilized silver nanoparticles in aqueous medium. Carbohydr. Polym. 2012, 89, 1159-1165. [CrossRef] [PubMed]

33. Do, J.Y.; Chava, R.K.; Kim, Y.I.; Cho, D.W.; Kang, M. Fabrication of Ag based ternary nanocomposite system for visible-light photocatalytic hydrogen evolution reaction. Appl. Surf. Sci. 2019, 494, 886-894. [CrossRef]

34. McNally, M.J.; Galinis, G.; Youle, O.; Petr, M.; Prucek, R.; Machala, L.; von Haeften, K. Silver nanoparticles by atomic vapour deposition on an alcohol micro-jet. Nanoscale Adv. 2019, 1, 4041-4051. [CrossRef]

35. Zhu, H.; Chen, D.; Li, N.; Xu, Q.; Li, H.; He, J.; Lu, J. Cyclodextrin-functionalized Ag/AgCl foam with enhanced photocatalytic performance for water purification. J. Colloid Interface Sci. 2018, 531, 11-17. [CrossRef]

36. Algarra, M.; Campos, B.B.; Radotić, K.; Mutavdžić, D.; Bandosz, T.; Jiménez-Jiménez, J.; Rodriguez-Castellón, E.; Esteves da Silva, J.C.G. Luminescent carbon nanoparticles: Effects of chemical functionalization, and evaluation of Ag+ sensing properties. J. Mater. Chem. A 2014, 2. [CrossRef]

37. Klastersky, J. Nosocomial infections due to Gram-negative bacilli in compromised hosts: Considerations for prevention and therapy. Rev. Infect. Dis. 1985, 7 (Suppl. 4), S552-S558. [CrossRef]

38. Wu, D.; Chan, W.; Metelitsa, A.; Fiorillo, L.; Lin, A. Pseudomonas skin infection: Clinical features, epidemiology, and management. Am. J. Clin. Dermatol. 2011, 12, 157-169. [CrossRef] 
39. Dayan, G.H.; Mohamed, N.; Scully, I.L.; Cooper, D.; Begier, E.; Eiden, J.; Jansen, K.U.; Gurtman, A.; Anderson, A.S. Staphylococcus aureus: The current state of disease, pathophysiology and strategies for prevention. Expert Rev. Vaccines 2016, 15, $1373-1392$. [CrossRef]

40. Chevalier, S.; Bouffartigues, E.; Bodilis, J.; Maillot, O.; Lesouhaitier, O.; Feuilloley, M.G.J.; Orange, N.; Dufour, A.; Cornelis, P. Structure, function and regulation of Pseudomonas aeruginosa porins. FEMS Microbiol. Rev. 2017, 41, 698-722. [CrossRef]

41. Liao, S.; Zhang, Y.; Pan, X.; Zhu, F.; Jiang, C.; Liu, Q.; Cheng, Z.; Dai, G.; Wu, G.; Wang, L.; et al. Antibacterial activity and mechanism of silver nanoparticles against multidrug-resistant Pseudomonas aeruginosa. Int. J. Nanomed. 2019, 14, $1469-1487$. [CrossRef] [PubMed]

42. Abdal Dayem, A.; Hossain, M.K.; Lee, S.B.; Kim, K.; Saha, S.K.; Yang, G.-M.; Choi, H.Y.; Cho, S.-G. The Role of Reactive Oxygen Species (ROS) in the Biological Activities of Metallic Nanoparticles. Int. J. Mol. Sci. 2017, 18, 120. [CrossRef] [PubMed]

43. Mao, B.-H.; Chen, Z.-Y.; Wang, Y.-J.; Yan, S.-J. Silver nanoparticles have lethal and sublethal adverse effects on development and longevity by inducing ROS-mediated stress responses. Sci. Rep. 2018, 8, 2445. [CrossRef] [PubMed]

44. Cameron, S.J.; Hosseinian, F.; Willmore, W.G. A Current Overview of the Biological and Cellular Effects of Nanosilver. Int. J. Mol. Sci. 2018, 19, 2030. [CrossRef] [PubMed]

45. Sobhanifar, S.; Worrall, L.J.; King, D.T.; Wasney, G.A.; Baumann, L.; Gale, R.T.; Nosella, M.; Brown, E.D.; Withers, S.G.; Strynadka, N.C.J. Structure and Mechanism of Staphylococcus aureus TarS, the Wall Teichoic Acid $\beta$-glycosyltransferase Involved in Methicillin Resistance. PLoS Pathog. 2016, 12, e1006067. [CrossRef] [PubMed]

46. Sobhanifar, S.; Worrall, L.J.; Gruninger, R.J.; Wasney, G.A.; Blaukopf, M.; Baumann, L.; Lameignere, E.; Solomonson, M.; Brown, E.D.; Withers, S.G.; et al. Structure and mechanism of Staphylococcus aureus TarM, the wall teichoic acid $\alpha$-glycosyltransferase. Proc. Natl. Acad. Sci. USA 2015, 112, E576-E585. [CrossRef]

47. Sim, W.; Barnard, R.T.; Blaskovich, M.A.T.; Ziora, Z.M. Antimicrobial Silver in Medicinal and Consumer Applications: A Patent Review of the Past Decade (2007-2017). Antibiotics 2018, 7, 93. [CrossRef]

48. Lambert, P.A. Cellular impermeability and uptake of biocides and antibiotics in Gram-positive bacteria and mycobacteria. J. Appl. Microbiol. 2002, 92, 46s-54s. [CrossRef] 